\title{
SPANXE Gene
}

National Cancer Institute

\section{Source}

National Cancer Institute. SPANXE Gene. NCI Thesaurus. Code C92972.

This gene may be involved in sperm differentiation. 